\title{
The Impact of Factors Related to the Audit of Financial Statements on Stock Returns: The Case of the Tunisian Market
}

\author{
Slim GHORBEL \\ Higher Institute of Business Administration of Sfax, Tunisia \\ Route de l'Aérodrome km 3, 5, Sfax 3018, Tunisia \\ E-mail: slim-ghorbel@planet.tn
}

Received: January 10, 2012

Accepted: February 10, 2012

Published: April 1, 2012

doi:10.5539/ijef.v4n4p163

URL: http://dx.doi.org/10.5539/ijef.v4n4p163

\begin{abstract}
This paper focuses on the analysis of the reactions of stock prices following the announcement of financial statements. Our contribution is to study the importance of variables related to the audit in explaining the reactions of stock returns. On the theoretical level, we have based our study on the theory of market information efficiency, the agency theory, signaling theory and corporate governance. Empirically, we used the event study method to test for abnormal reactions in stock prices following the announcement of financial statements, on a sample of 48 Tunisian listed companies. Our results show that the audit quality, the auditor's opinion and the co-commissioning have a joint impact on the evolution of stock prices. However, the recurrence of audit engagement has no effect.
\end{abstract}

Keywords: Stock returns, Audit, Event study

\section{Introduction}

Research in accounting and stock market reaction has developed in the early 1970 in the United States and in the early1990 in Europe. In fact, the empirical research dates back at least to the study of Ball and Brown and Beaver1968 on the market reactions to the publication of accounting results. Thus, what is most important in these studies was the investigation whether the announcement of earnings has high or low information contents. However, the announcement of quantitative information about accounting and finance is not enough to properly assess the stock market reaction.

Hence, there is a need for qualitative additional information. In fact, investors do not react as accounting numbers; they also react to less quantitative data such as ads on the strategies, restructuring, change management team and the deadline for publication of financial statements and auditors' reports.

In this sense, the current research may show the importance of information related to the audit as used by investors in their market valuation process. Hence, our problem is based on two main issues: Does the publication of audited financial statements influence stock returns? To what extent are factors related to the audit explaining such reactions important?

The paper is organized as follows: In section 1, we set the body of the theory. Section 2 presents our research hypotheses. Section 3 explains the methodological framework. In section 4, results are discussed. Section 5 concludes.

\section{Body of Theory}

With regard to the theoretical basis of this paper, the theory of informational efficiency is of paramount importance. Indeed, when considering the information content of disclosure (published accounting information), we need to know if we are part of an efficient financial market or not. In fact, an efficient market reflects all relevant information available for stock prices (Fama, 1970). Moreover, the theory of informational efficiency is that knowledge of information affecting the stock price which cannot allow its holder to make a profit on the market as other participants have the same information simultaneously. At this level, it is considered useful to present the theoretical basis of the audit and its relationship with stock returns of the securities, through the agency theory and the theory of signals.

\subsection{Role of Audit in the Agency Theory}

The audit is a type of control that helps to increase the firm's value by reducing the tendency of managers to manipulate the results (Jensen \& Meckling, 1976). Moreover, according to these authors, the external audit is a 
support alignment behaviour of the leader of the interests of shareholders, as well as formal control systems and budgetary restrictions. The external audit is, on the one hand, a monitoring mechanism providing an assessment of the conduct of management to shareholders and, on the other hand, a system to respond to a need for justification or obligation. To the extent that shareholders and creditors stare financial information of the company as a management control system, they can redeem themselves by providing this information, as well as having them certified by an independent external auditor.

\subsection{Role of Audit in the Context of the Theory of Signals}

Moore and Ronen (1990) maintain that managers hold internal information on the quality of their conduct while investors do not have this information. The difficulty of distinguishing the good from the terrible agents may lead to failure of the market for new securities because investors are conditional on the quality of managers. In this context, the demand for audit services is generated by the need to reduce the information asymmetry between managers and potential investors to assist in the acquisition of new capital. The purpose of external audit is currently inspecting the ability of the administration by verifying past financial reports. The demand for external audit can be interpreted as a system used by successful managers to make a good signal against investors.

\section{Research Hypotheses}

In what follows, we propose to present the research hypotheses that will be tested empirically.

\subsection{Hypothesis on the Quality Audit}

The impact of the external audit of stock prices is explained mainly by the risk of adverse selection that can cope with a market maker in a context of asymmetric information. Indeed, a high quality audit ensures the reliability of accounting data and allow users (including investors) to broadcast, trust accounts data communicated (Carassus \& Cormier, 2003, Fan and Wong, 2005). Moreover, the higher the quality of information, the less information asymmetry between investors and also the fewer opportunities are available to take advantage of informed private information they have to depend on the uninformed. To this end, various indicators and attributes were used in the accounting literature to assess the quality of audit. Among these attributes, we find the size of the firm corollary of its reputation and membership in a large international network "BIG4" or sectoral specialization of audit firms. Thus, a first hypothesis on the influence of audit quality on stock returns can be deduced:

Hypothesis 1: the reaction of investors in the financial market has more scope for companies audited by an international network (BIG4) than for companies not audited by a BIG.

\subsection{Hypothesis on the Co-Statutory Audit}

Co-statutory audit can be defined as the control by at least two competent and independent professionals both with reference to the controlled company to express an opinion on regularity, sincerity and fair presentation of financial statements. It should be noted that each of the co-designated auditors is individually responsible for the planning, implementation of the audit work they carry out and the views it expresses. This will have a direct impact as the procurement of the relationship of trust between the company and the various financial market players. Hence, a second hypothesis concerning the influence of the joint statutory auditors on the stock market can be deduced:

Hypothesis 2: An audit report on a company audited by two auditors affects stock prices over a report on a company audited by one auditor.

\subsection{Hypothesis Concerning the Auditor's Opinion}

The views expressed by the auditor have information content because they allow, on the one hand, reducing the conflict of interest between business owners and managers, and on the other hand, informing user's published opinion to make a quality decision. Thus, the timeliness of announcements of opinion enables the auditors to determine the quality of financial and accounting information. To this end, empirical tests on the relationship between the content of audit reports (with or without conditions) and the notion of timeliness of reporting (in early and late) are generally significant. Hence, we can deduce a third hypothesis concerning the influence of an audit opinion with reservations about the stock market:

Hypothesis 3: The magnitude of the response of stock prices of a company is related to the auditor's opinion (with or without conditions).

\subsection{Hypothesis Related to the Recurrence of the Mandates of the Auditor}

Suddaby et al. (2007) argue that the duration of the audit relationship influences the investors' perception of audit quality. Indeed, regulators and standard setters assume too long an association between auditor and client that may impair the independence of the auditor. Moreover, the work of Lu (2006) has shown a relationship between the 
recurrence of the mandates of the auditor and the behaviour of the investor. He concluded that when changing the audit there is a negative impact on the behaviour of the investor and on the propensity to manage the result. Thus, we can deduce a fourth hypothesis concerning the influence of the recurrence of the auditor's mandates on the stock market:

Hypothesis 4: An audit published report, prepared by an auditor whose mandate was renewed by the company concerned, affects stock prices more than a report by an auditor whose mandate was not renewed.

\section{Methodological Framework}

The main objective of our empirical study is to test the reaction of stock prices associated with the publication of audited financial statements. To conduct this study, we used the technique of event study analysis - also called abnormal returns or residuals - that allows studying the impact of a particular event in the stock market. This technique was created mainly with the work of Ball and Brown (1968) and Fama, Fisher, Jensen and Roll (1969). Following this early work, many events - announced by the company or not - such as the announcement of earnings (Ball and Brown, 1968), a distribution of dividends, Brickley (1983), a change in capital structure (Masulis, 1980), a takeover (Husson, 1988), the adoption of a new statutory instrument (Schipper and Thompson, 1983) and the development of an industrial crisis (safety and Pauchant, 1992), have applied the abnormal returns technique. However, despite the diversity of events studied, the methodological approach, which remains the same, generally consists of the following four main steps:

\subsection{Step 1: Identification of the Parameters of the Study}

In the literature, this step can often be only a brief and imprecise description. Yet it is the origin of the success of the study to the extent that misspecification of the parameters may affect the results. Therefore, it is convenient to define precisely the event, the announcement date and the periods of estimation and event.

\subsubsection{The Event}

As part of this research, the event studied is the publication of reports of business activity.

\subsubsection{The Announcement Date}

For some events, it is sometimes difficult to identify the exact date of the announcement. To avoid this problem, the solution is to study the market reaction, not the exact date of the first public announcement of the event but over an interval of time, called the event window, which revolves around the presumed date of announcement. Our sample consists of 48 Tunisian companies (belonging to the financial sector and non-financial one) as part of the permanent dimension of the Stock Exchange of Tunis (Tunis Stock Exchange). This sample is mainly composed of banks (11 banks) to the extent that they are the firms most frequently listed on the Tunisian stock market. Regarding the study period, the accounting data were taken during the period 2003-2007. Therefore, the number of observations amounts to 165 announcements external auditors' reports on the financial statements.

\subsubsection{The Estimation Periods and Event}

In our case, the study of events focuses on different dates of announcement relative to the annual publication of activity reports.

The estimation period allows evaluating the model parameters to calculate expected returns in the absence of event. The estimation period may be before, during or after the event. The choice generally depends on the model used to calculate the normal returns.

In the current study, the event window begins 15 days before the daily announcement date. This time interval is chosen so as to situate the event period between the beginning of the fiscal year and the publication of reports on the first half of the year. The estimation period is fixed at 30 days preceding the window.

\subsection{Step 2: Evaluation of Bond Yields Expected by Investors}

The event studies are designed to observe the stock market reaction to the announcement of an event. The impact on prices is measured by a yield difference, called residual or abnormal return. But, the profitability of an asset cannot be considered abnormal only in relation to a standard. This profitability, which corresponds to returns expected by investors in the absence of event, is called, in contrast, normal profitability.

The analysis of abnormal returns consists of three main parts. After defining models for establishing a standard, we first calculate the abnormal returns by the difference in returns actually recorded on the day of the event and the normal returns for each security. Then, the securities are grouped into several samples according to the weight of the explanatory variables (co-statutory audit, auditor's opinion, the auditor's reputation, etc). The average abnormal 
returns for each sample and each of the intervals of the study period are calculated to allow the calculation of the cumulative returns on part of the period. This will allow monitoring the impact of the event over time.

The last step is to check the validity of the results obtained by applying appropriate statistical tests that assess the extent to which results are significant.

\subsection{Step 3: Calculation of Residual Returns}

Once the second stage of the methodology of selecting a model for forecasting returns is completed (market model in our case), it becomes possible to determine the stock market reaction associated with the announcement of the event under study. These are measured by a yield spread between the rates observed during the event window and the rate normally expected by investors in the absence of event. This difference is called the residual or abnormal return. It is equal to:

$$
R A_{i t}=r_{i t}-E\left(r_{i t}\right)
$$

$R A_{i t}=$ abnormal return of security $i$ in period $t$

$r_{i t}=$ profitability of security $i$ during period $t$

$E\left(r_{i t}\right)=$ normal return, or expected, asset $i$ in period $t$.

\subsection{Step 4: Statistical tests of Abnormal Return}

In the present study, we adopt the Student test, as usually used to test statistically calculated abnormal returns. This choice is justified, on the one hand, by the Central Limit Theorem and, on the other hand, by the results of the simulation study conducted by Brown and Warner (1980). Indeed, it seems that the non normality of abnormal returns does not alter the effectiveness of the Student test to the extent that the Central Limit Theorem guarantees that the average abnormal returns converge rapidly to a normal distribution when the number of sample shares is large enough. In addition, the simulation results carried out by Brown and Warner indicate that non-parametric tests (sign test and Wilcoxon test) are less efficient than the Student test. Besides, analyzing the stock market reaction associated with the announcement of financial statements, the study allows the calculation of event, during a time interval surrounding the date of publication and rates of abnormal returns. These different levels of abnormal performance reflect how investors perceive the information in the financial statements. Be they positive or negative, they reflect the appreciation in the market for good or bad news.

\section{Results}

\subsection{The Influence of Publication of Financial Statements under Audit Quality}

In our methodological approach, we chose to distinguish the announcements of financial statements under audit quality (audited by Big 4 or not). (Appendix, Table 1). For both sub-samples, we note the absence of significant abnormal returns for the days preceding the date of the event. In addition, Figure 1 shows the distribution of audit reports according to their memberships Big 4 and No Big 4 of the study period 2003-2007.

From the date of the event, we note a highly significant investor reaction, embodied by the sudden increase in abnormal returns in the negative direction. The cumulative average abnormal returns diminish. But, from date 3 , we see a return of the variation in cumulative average abnormal returns continuing until date 5 . This reversal is still low compared to overreact generated by dates 0 and 1 . Between dates 0 and 2, we see a strong response from investors who weaken proportionally after the date of the event. There are two significant impacts in the same direction, similar to those obtained on the entire sample, but significantly lower magnitude in the sub-sample audited by non Big. Indeed, this result can be explained by the fact that large firms are more conservative in their view than small competitor's reputation. This propensity for caution does allow users to ensure investors and others in the financial market against possible misuse of accounts. Otherwise, investors in the Tunisian market have confidence in the financial statements published by Big.

In conclusion, investors in financial markets attach great importance to the financial statements audited by a BIG compared to the financial statements audited by a no BIG. Where partial confirmation of $\mathrm{H} 1$.

\subsection{The Influence of Publication of Financial Statements in the Auditor's Opinion}

This hypothesis aims to assess the quality of the content of auditors' reports. It fits into the context of the problems with the difference of opinion regarding the role and usefulness of the audit function. We examine the behaviour of stock prices around the date at which the auditors have reservations on the financial statements with the behaviour of the shares of companies with an unqualified audit report. Our empirical study contains 48 Tunisian companies which have published their financial statements together with the external auditors' reports to the Board of the 
Tunisian financial market over a period of five years. The number of audit reports is the order of 187, of which 64 are "subject" and the remaining 101 are "unqualified". (Appendix, Table 2).

The Figure 4 shows the results for the reserves reported by the auditors in the annual and consolidated reports of the two subsamples (compared with reserves and report without reserves). The results show a negative performance around the event date. The average abnormal return is negative and insignificant one day before the event date for the two subsamples. After the date zero, the abnormal return is negative and significant. The magnitude of the negative returns in the following days is becoming increasingly important in the category of companies (dealing with reserves).

Indeed, the average abnormal returns are negative and especially in the interval $1,+3$ (one day and three days after the event). This shows that the market reacts to bad news (compared with reserves). In general, the reserves expressed by the auditors have a negative impact on stock prices. Otherwise, investors in the Tunisian stock market attach importance to the opinions of the auditor and above all the bad news (reports with reserves).

In conclusion the auditor's opinion is an important determinant of stock prices following the announcement of financial statements, where confirmation of $\mathrm{H} 2$.

\subsection{The Influence of Publication of Financial Statements under the Co-Statutory Audit}

In the present section, we try to check whether the effect of the joint commission can be a determinant of stock price reaction to the stock market in Tunisia. In this case, we need a significant change at the level of abnormal returns generated by companies to co-statutory audit with respect to those without co-statutory auditor. To classify companies according to this criterion, we use the annual reports signed only by one or two auditors. In addition, the table 3 in the appendix shows the distribution of audit reports by the co-statutory auditor factor.

The figure 5 shows different results between the two subsamples. For instance, for companies in the subsample with no co-statutory audit, the reaction of investors starts at time 0 and continues for the dates 1 and 2 . Besides, In terms of variation in the level of abnormal returns, the date 0 has the highest level of variation. This variation in the level of cumulative average abnormal returns does not continue for dates 1 and 2. From the 5th day, we note the stability of the reaction of these returns. For dates 0 and 1, they are statistically significant. Then, for companies in the subsample with co-statutory audit, the reaction of the average cumulative abnormal returns starts from the date -1 and continues to date 2 . The variation of the reaction reaches its maximum value at time 0 . From date 5 , we remark the stability of the returns reactions. As for dates 0,1 and 2 , they are statistically significant. We note that the superiority of the abnormal returns of companies with no co- statutory audit, reaches a value equal to 4 times for the date 0 compared to companies with co- statutory audit. However, we record a more rapid decline in abnormal returns of companies audited by co- statutory audit with respect to those companies audited by one auditor. This leads us to conclude that investors in the Tunisian stock market give importance to the phenomenon of co- statutory audit of the financial statements and allocate a lot of confidence to the financial statements audited by two auditors more those audited by a single auditor.

In conclusion, the co-statutory audit is a factor in the reaction of investors following the announcement of financial statements, which confirms H3.

\subsection{The Influence of the Publication of Financial Statements in the Number of Terms of Auditors}

In this section, we try to check whether the effect of recurrence of the audit engagement is a determinant of the response of stock prices. In this case, we need a significant change in the level of abnormal returns generated by the companies" mission-shot "compared to those with recurrence of mission. To do this, we subdivide our sample into two groups. The first group represents companies with "no recurrence of mission "and the second those with "recurrence of mission."

The table 4 and the Figure 7 in appendices present similar results for both subsamples, that is to say, for companies with a recurring audit engagement and companies with no recurrence of mission of audit. For the group of companies "recurring mandate", we note that the reaction of investors starts from the date of the event. This reaction is represented by a strong variation of abnormal returns, from the date -1. It continues for a date. From the date 2, we find stability of the variation in abnormal returns. Cumulative average abnormal returns of the corporate group are statistically significant for time 0 and 1 . For the group of companies "no recurring mandate ", we note that the reaction of investors starts from the date of the event but it continues for a date. After that, we note the disruption of this reaction and return to the abnormal returns 0 . The cumulative abnormal average returns of "no recurrence of mission" companies are statistically significant for time 0 and 1 . This allows us to conclude that the same trend of response in the two subsamples. The two subsamples do not mark a difference in the reaction of investors. For company's recurring mission, we see two phases of reaction. The first phase covers the period preceding the date of 
the event. This reaction generated the increase in the level of abnormal returns in the positive direction. From the date of the event, the reaction is reversed to lower abnormal returns and closer to 0. Statistically, the abnormal returns are significant for time 0 and 1. For company's recurring mission, we virtually consider responses from investors. As a result, investors on the Tunisian stock market are indifferent to the recurrence of the audit of financial statements. This reverses the effect of "recurring audit engagement" and may be a determinant factor of the reaction of stock market prices.

In conclusion, the recurrence of audit engagement has no effect on the reaction of stock market prices, hence the rejection of $\mathrm{H} 4$.

\section{Conclusion}

This research paper fits into the context of the problems with the role and utility of the accounting and financial audit in explaining stock returns. This paper aimed to assess the quality of the content of the reports of the auditors in the Tunisian financial market through empirical tests with four assumptions. The main results reveal that the variables related to audit quality (reputation, auditor's opinion and the co-statutory audit) have a general impact on the evolution of stock prices. Thus, our results lead us to reconsider the role of the auditor in corporate governance. Finally, despite the progress made in the publication of financial and accounting information, much remains to be done to meet the demands of investors and other interested parties in the matter. However, these improvements can be achieved only through close cooperation between the oversight body for listed companies, accountants and academics.

\section{References}

Baker, R., \& Owsen, D. (2002). Increasing the role of auditing in corporate governance. Critical Perspectives on Accounting, 13: 783- 795.

Ball, R., \& Brown, P. (1968). An empirical evaluation of accounting income numbers. Journal of Accounting Research, 6:159-178.

Brickley, J. (1983). Shareholder wealth, information signalling and the specially designated dividends: An empirical study. Journal of Financial Economics, 12:187-210.

Brown, SJ., Warner, JB. (1980). Measuring Security Price Performance. Journal of Financial Economics, 8: 205-258.

Carassus, D., \& Cormier, D. (2003). L'évaluation du risque de fraude comme objet d'analyse de l'audit externe légal. Comptabilité, Contrôle, Audit, printemps.

Carey, P., \& Simnett, R. (2006). Audit Partner Tenure and Audit Quality. Accounting Review, 81(3): 653-676.

Chalmers, K., \& Godfrey, JM. (2004). Reputation costs: the impetus for discretionary derivative financial instrument reporting. Accounting, Organizations and Society, 29:95-125.

Charreaux, G. (2008). La recherche en finance d'entreprise: quel positionnement méthodologique ? Revue Finance Contrôle Stratégie, Editions Economica. 11: 237-290.

Clark ,T., Cornwell, B., \& Stephen, PW. (2009). The impact of title event sponsorship announcements on wealth. 20( 2), 169-185.

Fama, EF., Fisher, L., Jensen, \& MC., \& Roll, R. (1969). The Adjustment of Stock Prices to New Information. International Economic Review, 10(1),1-21.

Fama, EF. (1970). Efficient Capital Markets: A Review of Theory and Empirical Work. The Journal of Finance, XXV.2:383-417.

Fan, JPH., \& Wong, TJ. (2002). Corporate ownership structure and the informativeness of accounting earnings in East Asia. Journal of Accounting and Economics, 33:401- 425.

Favere, M., \& Emby Cen. (2005). The Impact of Continuity on Concurring Partner Reviews: An Exploratory Study. Accounting Horizons, 19(1), 1-10.

Jensen, MC., \& Meckling, WH. (1976). Theory of the Firm: Managerial Behaviour, Agency Costs and Ownership Structure. Journal of Financial Economics, 3(4), 305-360.

LU, T. (2006). Does Opinion Shopping Impair Auditor Independence and Audit Quality? Journal of Accounting Research, 44(3), 561-83.

Masulis, RW. (1983). The Impact of Capital Structure Change on Firm Value: Some Estimates. Journal of Finance, $38,107-126$. 
Moore, G., \& Ronen, J. (1990). External audit and asymmetric information. Auditing: Journal of Practice and Theory, 9, 234-242.

Pittman, J., \& Fortin, S. (2004). Auditor choice and the cost of debt capital for newly public firms. Journal of Accounting and Economics. 37,113-136.

RAKOTO, P. (2005). Caractéristiques de l'information, surcharge d'information et qualité de la prédiction. Comptabilité -Contrôle- Audit, 1, 23-38.

Suddaby, R., Cooper, D J., \& GREENWOOD, R. (2007). Transnational Regulation of Professional Services: Governance Dynamics of Field Level Organizational Change. Accounting, Organizations and Society, 32(4-5), 333-362.

Wiles, A., Danielova, A. (2009). The Worth of Product Placement in Successful Films: An Event Study Analysis. Journal of marketing, 73(4).

Table 1 . The influence of publication of financial statements under audit quality

\begin{tabular}{|c|c|c|c|c|c|}
\hline \multirow[t]{3}{*}{ Event } & \multirow[t]{3}{*}{ Day } & \multicolumn{2}{|c|}{ Controled by a Big } & \multicolumn{2}{|c|}{ Controled by a no Big } \\
\hline & & \multicolumn{2}{|c|}{$\mathrm{N}=55$} & \multicolumn{2}{|c|}{$\mathrm{N}=110$} \\
\hline & & RAM & TRASM & RAM & TRASM \\
\hline & -15 & $-0,0108$ & 0,0214 & 0,4622 & 0,4622 \\
\hline & -14 & $-0,0110$ & 0,2814 & 0,8515 & 0,8515 \\
\hline & -13 & $-0,0113$ & 0,8254 & 0,9932 & 0,9932 \\
\hline & -12 & $-0,0115$ & 2,5477 & 1,8128 & 1,8128 \\
\hline & -11 & $-0,0117$ & 1,4369 & 0,2663 & 0,2663 \\
\hline & -10 & $-0,0120$ & 1,6896 & 0,9335 & 0,9335 \\
\hline & -9 & $-0,0122$ & 0,3126 & 3,0690 & 3,0690 \\
\hline & -8 & $-0,0125$ & 1,1134 & 2,7757 & 2,7757 \\
\hline & -7 & $-0,0127$ & 0,2982 & 1,5152 & 1,5152 \\
\hline & -6 & $-0,0130$ & 1,1551 & 0,9422 & 0,9422 \\
\hline & -5 & $-0,0133$ & 1,9064 & $-0,0134$ & 0,8938 \\
\hline & -4 & $-0,0040$ & 0,7870 & $-0,0300$ & 1,0957 \\
\hline & -3 & 0,0015 & 0,7842 & $-0,0288$ & 0,1240 \\
\hline & -2 & 0,0129 & 1,6849 & $-0,0365$ & 0,6663 \\
\hline & -1 & 0,0155 & 0,4515 & $-0,0183$ & 2,6005 \\
\hline & 0 & $-0,0161$ & 4,1968 & $-0,0614$ & 3,9523 \\
\hline & 1 & $-0,0317$ & 2,8419 & $-0,1046$ & 3,4188 \\
\hline & 2 & $-0,0422$ & 1,4547 & $-0,0999$ & 0,3635 \\
\hline & 3 & $-0,0395$ & 0,4184 & $-0,1053$ & 0,4525 \\
\hline & 4 & $-0,0279$ & 1,4858 & $-0,1031$ & 0,2187 \\
\hline & 5 & $-0,0196$ & 1,3047 & $-0,1137$ & 1,3052 \\
\hline & 6 & $-0,0192$ & 2,0456 & $-0,1114$ & 0,5115 \\
\hline & 7 & $-0,0188$ & 1,3468 & $-0,1091$ & 1,2143 \\
\hline & 8 & $-0,0184$ & 0,2741 & $-0,1070$ & 1,2085 \\
\hline & 9 & $-0,0180$ & 0,5495 & $-0,1048$ & 0,4069 \\
\hline & 10 & $-0,0177$ & 0,9132 & $-0,1027$ & 1,6870 \\
\hline & 11 & $-0,0173$ & 1,0421 & $-0,1007$ & 0,8682 \\
\hline & 12 & $-0,0170$ & 0,7267 & $-0,0987$ & 0,9506 \\
\hline & 13 & $-0,0166$ & 1,2869 & $-0,0967$ & 1,3996 \\
\hline & 14 & $-0,0163$ & 0,2267 & $-0,0947$ & 1,9669 \\
\hline & 15 & $-0,0160$ & 0,3723 & $-0,0929$ & 1,3425 \\
\hline
\end{tabular}

N: number of announcements of audit reports for the period 2003-2007.

RAM: outputs abnormal means.

TRASM: abnormal output test after standardization. 
Table 2. The influence of publication of financial statements in the auditor's opinion

\begin{tabular}{|c|c|c|c|c|c|}
\hline \multirow[t]{3}{*}{ Event } & \multirow[t]{3}{*}{ Day } & \multicolumn{2}{|c|}{ Report with reserves } & \multicolumn{2}{|c|}{ Report without reserves } \\
\hline & & \multicolumn{2}{|c|}{$\mathrm{N}=64$} & \multicolumn{2}{|c|}{$\mathrm{N}=101$} \\
\hline & & RAM & TRASM & RAM & TRASM \\
\hline & -15 & $-0,0143$ & 0,7371 & $-0,0176$ & 1,1238 \\
\hline & -14 & $-0,0146$ & 0,7403 & $-0,0180$ & 0,9796 \\
\hline & -13 & $-0,0149$ & 0,1590 & $-0,0183$ & 0,4556 \\
\hline & -12 & $-0,0152$ & 0,1666 & $-0,0187$ & 1,4515 \\
\hline & -11 & $-0,0155$ & 0,3103 & $-0,0191$ & 0,8714 \\
\hline & -10 & $-0,0159$ & 1,0324 & $-0,0195$ & 0,3859 \\
\hline & -9 & $-0,0162$ & 0,3053 & $-0,0199$ & 1,3597 \\
\hline & -8 & $-0,0165$ & 0,9663 & $-0,0203$ & 1,0320 \\
\hline & -7 & $-0,0169$ & 1,7713 & $-0,0207$ & 0,8626 \\
\hline & -6 & $-0,0172$ & 0,5068 & $-0,0211$ & 0,7497 \\
\hline & -5 & $-0,0176$ & 1,5379 & $-0,0216$ & 2,8624 \\
\hline & -4 & $-0,0425$ & 1,7373 & $-0,0223$ & 0,1099 \\
\hline & -3 & $-0,0456$ & 0,2367 & $-0,0345$ & 1,2536 \\
\hline & -2 & $-0,0529$ & 0,6530 & $-0,0296$ & 0,6998 \\
\hline & -1 & $-0,0529$ & 0,0016 & $-0,0260$ & 0,6167 \\
\hline & 0 & $-0,0470$ & 0,5122 & $-0,0160$ & 2,3663 \\
\hline & 1 & $-0,0321$ & 2,3908 & $-0,0118$ & 0,6065 \\
\hline & 2 & $-0,0306$ & 2,1333 & $-0,0157$ & 0,6397 \\
\hline & 3 & $-0,0228$ & 0,4649 & $-0,0007$ & 2,4074 \\
\hline & 4 & $-0,0274$ & 0,4428 & 0,0090 & 1,4084 \\
\hline & 5 & $-0,0455$ & 1,5662 & 0,0142 & 0,9337 \\
\hline & 6 & $-0,0445$ & 0,2406 & 0,0139 & 0,2814 \\
\hline & 7 & $-0,0436$ & 1,3109 & 0,0136 & 0,8254 \\
\hline & 8 & $-0,0428$ & 1,4627 & 0,0133 & 2,5477 \\
\hline & 9 & $-0,0419$ & 1,8494 & 0,0130 & 1,4369 \\
\hline & 10 & $-0,0411$ & 0,3144 & 0,0128 & 1,6896 \\
\hline & 11 & $-0,0403$ & 0,5117 & 0,0125 & 0,3126 \\
\hline & 12 & $-0,0394$ & 0,8205 & 0,0123 & 1,1134 \\
\hline & 13 & $-0,0387$ & 0,5655 & 0,0120 & 0,2982 \\
\hline & 14 & $-0,0379$ & 0,3115 & 0,0118 & 1,1551 \\
\hline & 15 & $-0,0371$ & 0,0214 & 0,0116 & 0,4622 \\
\hline
\end{tabular}

N: number of announcements of audit reports for the period 2003-2007.

RAM: outputs abnormal means.

TRASM: abnormal output test after standardization. 
Table 3. The influence of the publication of financial statements in the number of auditors

\begin{tabular}{|c|c|c|c|c|c|}
\hline \multirow[t]{3}{*}{ Event } & \multirow[t]{3}{*}{ Day } & \multicolumn{2}{|c|}{ Report with co-statutory audit } & \multicolumn{2}{|c|}{ Report without co-statutory audit } \\
\hline & & \multicolumn{2}{|c|}{$\mathrm{N}=81$} & \multicolumn{2}{|c|}{$\mathrm{N}=84$} \\
\hline & & RAM & TRASM & RAM & TRASM \\
\hline & -15 & 0,0168 & 0,0261 & 0,0168 & 0,3075 \\
\hline & -14 & 0,0172 & 2,8383 & 0,0172 & 0,2987 \\
\hline & -13 & 0,0175 & 1,0885 & 0,0175 & 0,4122 \\
\hline & -12 & 0,0179 & 0,4017 & 0,0179 & 0,4597 \\
\hline & -11 & 0,0182 & 0,3393 & 0,0182 & 0,1559 \\
\hline & -10 & 0,0186 & 0,5840 & 0,0186 & 0,0066 \\
\hline & -9 & 0,0190 & 0,6967 & 0,0190 & 0,5970 \\
\hline & -8 & 0,0194 & 1,5318 & 0,0194 & 0,1831 \\
\hline & -7 & 0,0198 & 0,5343 & 0,0198 & 0,0595 \\
\hline & -6 & 0,0202 & 0,2399 & 0,0202 & 1,0852 \\
\hline & -5 & 0,0206 & 0,2151 & 0,0206 & 0,1752 \\
\hline & -4 & 0,1449 & 1,1959 & 0,1654 & 1,1729 \\
\hline & -3 & 0,1293 & 0,1260 & 0,2948 & 0,0786 \\
\hline & -2 & 0,0500 & 0,7578 & 0,3448 & 0,7108 \\
\hline & -1 & 0,2151 & 1,9551 & 0,5599 & 1,5106 \\
\hline & 0 & 0,2223 & 2,0691 & 0,7821 & 2,0077 \\
\hline & 1 & 0,0133 & 2,5515 & 0,7954 & 1,9691 \\
\hline & 2 & $-0,1673$ & 2,0486 & 0,6282 & 1,6697 \\
\hline & 3 & $-0,2974$ & 1,8741 & 0,3307 & 1,0341 \\
\hline & 4 & $-0,4005$ & 0,6718 & $-0,0698$ & 0,7932 \\
\hline & 5 & $-0,3938$ & 0,0474 & $-0,4636$ & 0,1423 \\
\hline & 6 & $-0,3859$ & 1,0395 & $-0,4543$ & 0,7664 \\
\hline & 7 & $-0,3782$ & 0,7293 & $-0,4452$ & 1,6850 \\
\hline & 8 & $-0,3706$ & 1,1978 & $-0,4363$ & 0,5877 \\
\hline & 9 & $-0,3632$ & 0,4038 & $-0,4276$ & 0,2639 \\
\hline & 10 & $-0,3560$ & 1,3885 & $-0,4191$ & 0,9214 \\
\hline & 11 & $-0,3488$ & 0,0287 & $-0,4107$ & 1,7122 \\
\hline & 12 & $-0,3419$ & 1,1973 & $-0,4025$ & 0,2741 \\
\hline & 13 & $-0,3350$ & 0,4418 & $-0,3944$ & 0,0822 \\
\hline & 14 & $-0,3283$ & 0,3732 & $-0,3865$ & 0,4219 \\
\hline & 15 & $-0,3218$ & 0,6424 & $-0,3788$ & 1,1461 \\
\hline
\end{tabular}

N: number of announcements of audit reports for the period 2003-2007.

RAM: outputs abnormal means.

TRASM: abnormal output test after standardization. 
Table 4. The influence of the publication of financial statements in the number of terms of auditors

\begin{tabular}{|c|c|c|c|c|c|}
\hline \multirow[t]{3}{*}{ Event } & \multirow[t]{3}{*}{ Day } & \multicolumn{2}{|c|}{ Report with only one mandate } & \multicolumn{2}{|c|}{ Report with several mandates } \\
\hline & & \multicolumn{2}{|c|}{$\mathrm{N}=102$} & \multicolumn{2}{|c|}{$\mathrm{N}=63$} \\
\hline & & RAM & TRASM & RAM & TRASM \\
\hline & -15 & $-0,0113$ & 1,3163 & $-0,0105$ & 1,3163 \\
\hline & -14 & $-0,0115$ & 1,2359 & $-0,0107$ & 1,2359 \\
\hline & -13 & $-0,0117$ & 0,5593 & $-0,0109$ & 0,5593 \\
\hline & -12 & $-0,0120$ & 1,0462 & $-0,0111$ & 1,0462 \\
\hline & -11 & $-0,0122$ & 0,1197 & $-0,0113$ & 0,1197 \\
\hline & -10 & $-0,0125$ & 1,3642 & $-0,0116$ & 1,3642 \\
\hline & -9 & $-0,0127$ & 1,3380 & $-0,0118$ & 1,3380 \\
\hline & -8 & $-0,0130$ & 1,8481 & $-0,0120$ & 1,8481 \\
\hline & -7 & $-0,0133$ & 0,1148 & $-0,0123$ & 0,1148 \\
\hline & -6 & $-0,0135$ & 0,1872 & $-0,0125$ & 0,1872 \\
\hline & -5 & $-0,0138$ & 1,4440 & $-0,0128$ & 1,1283 \\
\hline & -4 & $-0,0183$ & 0,2976 & $-0,0116$ & 0,1123 \\
\hline & -3 & $-0,0180$ & 0,0288 & $-0,0045$ & 1,1468 \\
\hline & -2 & $-0,0071$ & 1,1520 & $-0,0083$ & 0,4669 \\
\hline & -1 & $-0,0065$ & 0,0694 & 0,0090 & 2,1682 \\
\hline & 0 & $-0,0367$ & 3,3257 & $-0,0334$ & 4,8190 \\
\hline & 1 & $-0,0575$ & 1,9940 & $-0,0667$ & 3,4226 \\
\hline & 2 & $-0,0656$ & 0,8214 & $-0,0671$ & 0,0386 \\
\hline & 3 & $-0,0666$ & 0,1241 & $-0,0674$ & 0,0363 \\
\hline & 4 & $-0,0782$ & 1,1773 & $-0,0412$ & 3,7749 \\
\hline & 5 & $-0,0834$ & 0,6571 & $-0,0350$ & 0,9865 \\
\hline & 6 & $-0,0817$ & 1,2253 & $-0,0343$ & 1,1937 \\
\hline & 7 & $-0,0801$ & 0,3383 & $-0,0336$ & 1,2798 \\
\hline & 8 & $-0,0785$ & 0,3285 & $-0,0329$ & 1,4957 \\
\hline & 9 & $-0,0769$ & 0,4534 & $-0,0323$ & 1,1352 \\
\hline & 10 & $-0,0754$ & 0,5056 & $-0,0316$ & 0,9489 \\
\hline & 11 & $-0,0739$ & 0,1714 & $-0,0310$ & 0,8248 \\
\hline & 12 & $-0,0724$ & 0,0073 & $-0,0304$ & 0,2647 \\
\hline & 13 & $-0,0710$ & 0,6567 & $-0,0298$ & 1,4420 \\
\hline & 14 & $-0,0695$ & 0,2014 & $-0,0292$ & 1,6090 \\
\hline & 15 & $-0,0681$ & 0,0654 & $-0,0286$ & 0,3459 \\
\hline
\end{tabular}

N: number of announcements of audit reports for the period 2003-2007.

RAM: outputs abnormal means.

TRASM: abnormal output test after standardization. 


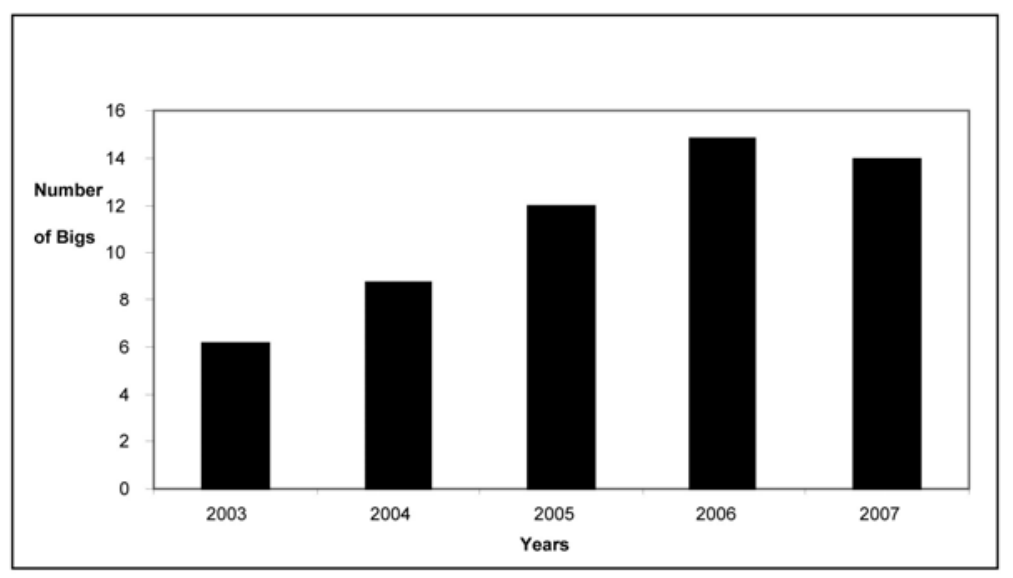

Figure 1. Changes in the number of reports audited by Bigs

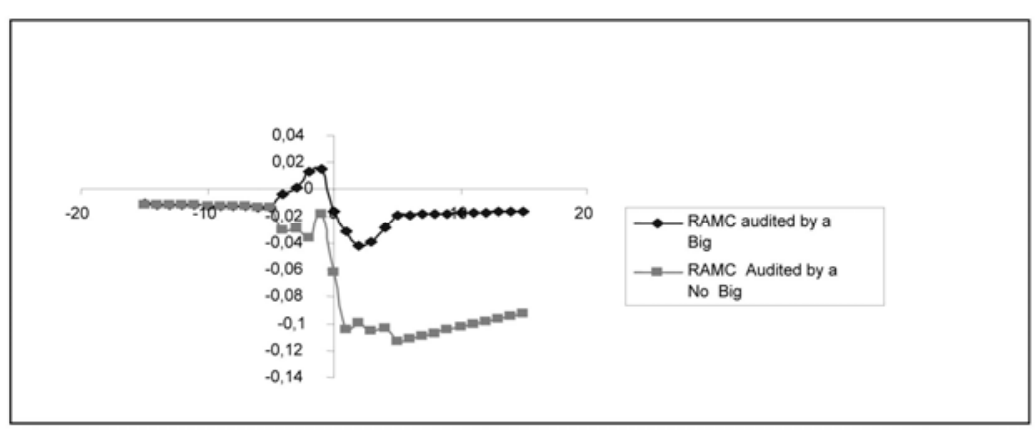

Figure 2. The influence of publication of financial statements under audit quality

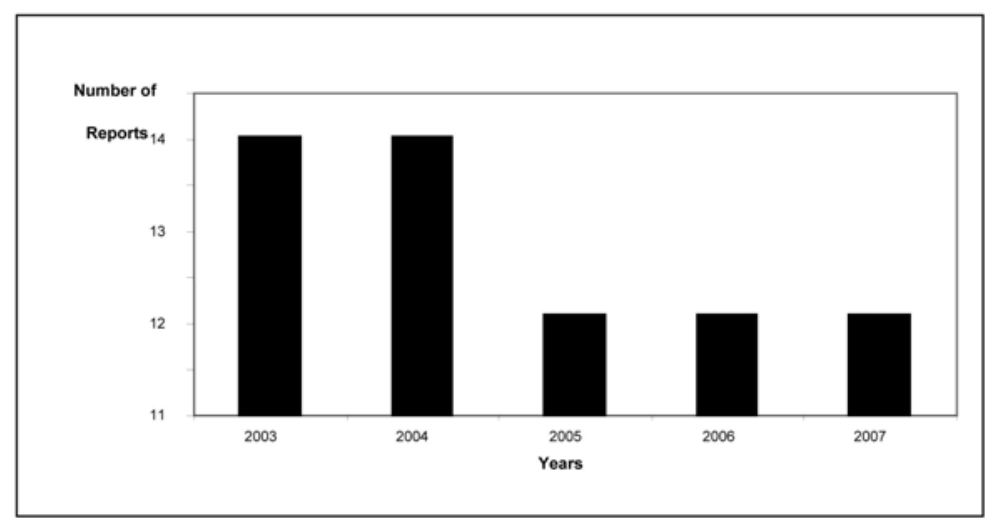

Figure 3. Evolution of number of reports with reserves

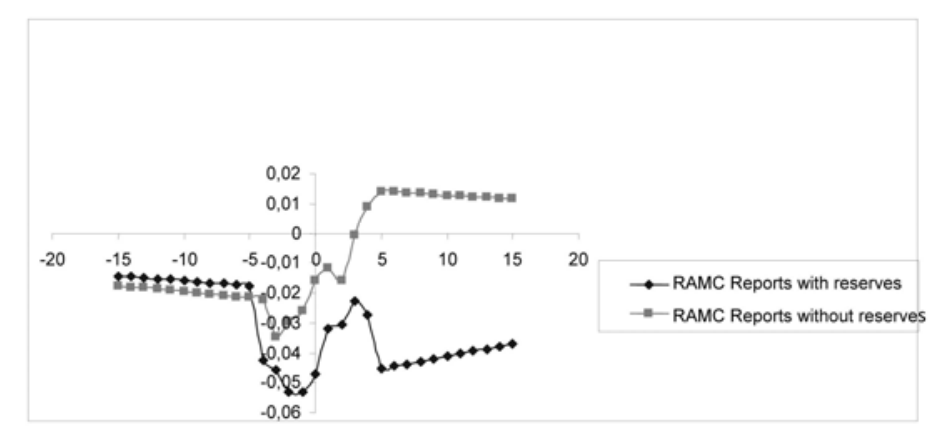

Figure 4. The influence of publication of financial statements in the auditor's opinion 


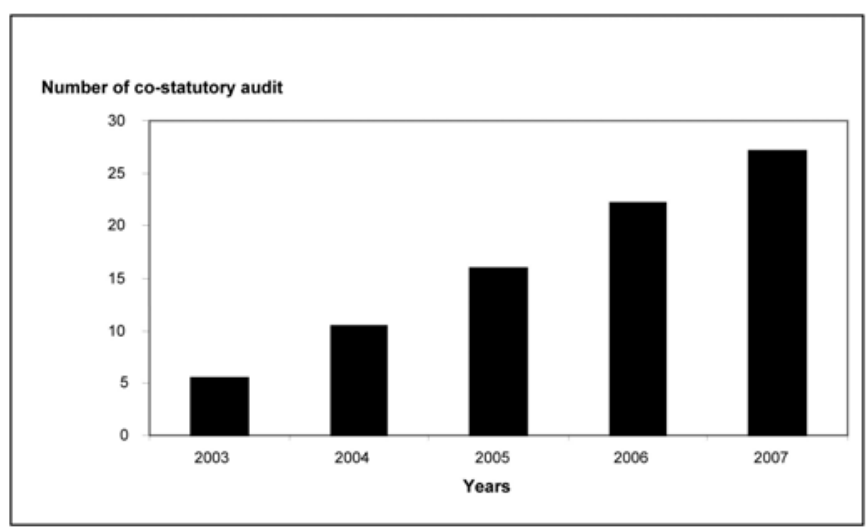

Figure 5. Evolution of number of missions of co-statutory audit

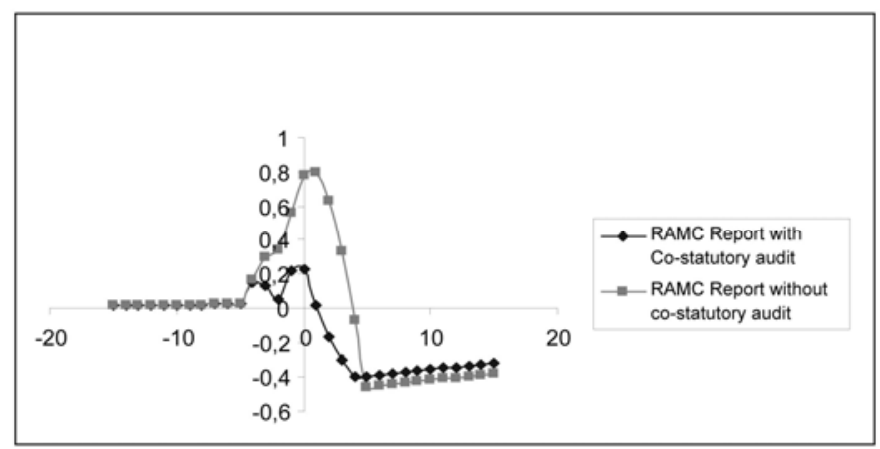

Figure 6. The influence of the publication of financial statements in the number of auditors

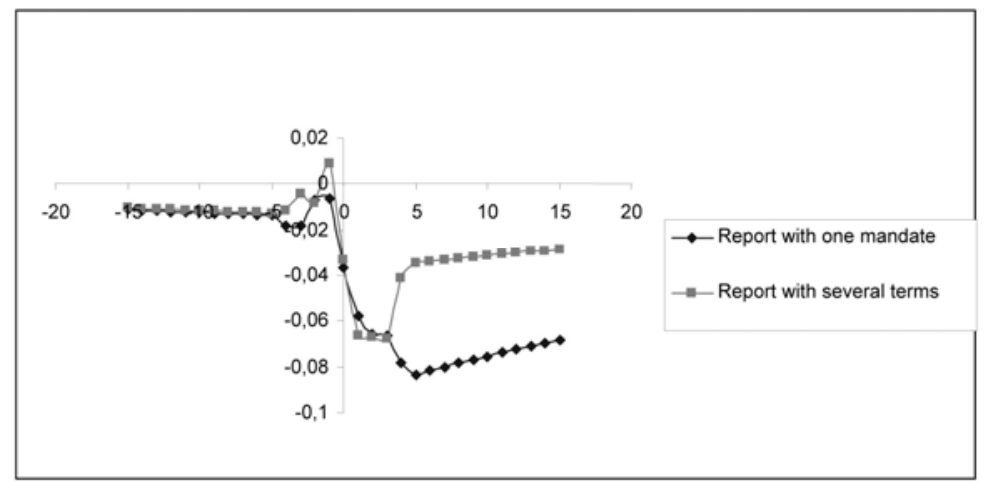

Figure 7. The influence of the publication of financial statements in the number of terms of auditors 